\title{
THE EFFECT OF GUIDED IMAGERY-RELAXATION TECHNIQUE ON THE INTENSITY OF PAIN IN ADOLESCENT WITH PRIMARY DYSMENORRHEA
}

\author{
Yayat Suryati, Nissa Agustin \\ Stikes Jenderal Achmad Yani Cimahi \\ Correspondence: yayat suryati@yahoo.co.id
}

\begin{abstract}
The incidence of dysmenorrhea cases in Indonesia was about $45-95 \%$ and $70-90 \%$ of cases occurred in adolescence. There are two types of treatment for dysmenorrhoea, namely pharmacological and nonpharmacological therapy. One of the non-pharmacological techniques is guided imagery by doing relaxation. The purpose of this study is to assess the effect of guided imagery on dysmenorrhoea intensity in adolescents. The research applied the quasi-experiment design with the one-group pretest-posttest design. The samples were students of Cimahi senior high school. The samples were chosen using purposive sampling technique. There were 28 respondents involved in this study. The data collection was performed by measuring the scale of pain with the Numeric Rating Scale and then giving intervention of guided imagery- relaxation technique. The interventions were applied base on the standard operating procedure. Intervention is done once a day on the first day of the menstruation period. The data were analyzed using univariate analysis and bivariate analysis. The univariate measured median of data and bivariate applied the Wilcoxon test. The univariate analysis found that the median before the result of dysmenorrhea pain scale before guided imagery- relaxation technique was 5.00 and after the interventions were 2.50. The statistical test found $\mathrm{P}$ value of $0,000<\alpha(0,05)$. The finding found Ha failed and rejected, it means there was an influence of guided imagery- relaxation technique on the pain intensity in adolescents with dysmenorrhea. It is expected that health institutions share this finding and apply this method to help the adolescent in dealing with dysmenorrhea.
\end{abstract}

Keywords: Adolescent, Dysmenorrhea, Guide Imagery, Relaxation.

\section{INTRODUCTION}

Adolescence period is a transition period from childhood to adulthood. In this period, there is a rapid growth of children including reproductive organs and functions. This growth may affect the physical, mental and roles in society (Kumalasari \& Andhyanto, 2012). The World Health Organization (WHO) stated that approximately one-fifth of the world's population are teenagers' age 10-19 years and about 900 million of them lived in developing countries. The demographic data of the United States found that the number of adolescents age 10 -19 years were about $15 \%$ of the population. In the Asia Pacific region in which $60 \%$ of the world's population, one-fifth of it were adolescents (10 -19 years) (Soetjoningsih, 2010). 
The Indonesian statistic bureau (BPS) reported Indonesian population was 237.6 million and 63.4 million of them are teenagers. The teenager's population consisted of 32,164,436 men (50.70\%) and 31,279,012 were female (49,30\%) (Ramadani, 2014). Adolescence is identic with puberty. The puberty is a stage of human development characterized by the maturity of the sexual and reproductive organs. One of the puberty characteristics in female teenagers is the first menstruation (menarche).

Dysmenorrhoea is pain that may occur before and during the menstrual period. The characteristic of dysmenorrhea is cramping or discomfort in the lower abdomen, spreading around the waist and thighs, followed by headaches, thus impacted women's activities such as working. Women take a break from their job for several hours or days because of dysmenorrhea (Prawirohardjo, 2014).

This dysmenorrhea commonly occurs on the 2nd or 3rd years after menarche and reaches its peak when women are 15-25 years old (Simanjuntak, 2008). Dysmenorrhoea is divided into two categories primary and secondary. Primary dysmenorrhea occurs usually after 12 months or more after menarche. Pain arose before or in the same day of menstruation. It might be because of several intrinsic uterine factors, including hormonal imbalances without any organic abnormalities in the pelvis. While the secondary dysmenorrhea is caused by gynecologic abnormalities and occurred in women with age more than 20 years (Proverawati and Misaroh, 2009).

The incidence of dysmenorrhoea in the world is large. On average more than $50 \%$ of women in each country experienced menstrual pain. In Indonesia, the prevalence of dysmenorrhoea ranges from $45-95 \%$ among women in the childbearing age (Proverawati and Misaroh, 2009) and around 70-90\% cases of menstrual pain were adolescence (Puji, 2011). 
One effect of untreated dysmenorrhoea was discomfort in daily activities, for example, absences at school or at the workplace. Adolescents with dysmenorrhea may be affected by academic, social and sports activities, or decreasing their productivity (Puji, 2011). There are two categories of treatments for dysmenorrhea: pharmacological and non- pharmacological.

The preliminary study has been done on March 13, 2017, in class X (10) in SMA Negeri 5 Cimahi by interviewing 10 female students with dysmenorrhoea experience, 3 out 10 students had severe pain, 4 students had moderate pain, 2 students had light pain, and another one did not feel pain. The preliminary study also assessed the pain duration, two of them said that they suffered pain for 4 days, 7 students said less than 3 days, and another one did not feel pain. In regard to student activities, the researcher assessed whether dysmenorrhea disrupts their activities, 6 female students said dysmenorrhea interfere in their activities in school and 4 female students said they were fine with their activities. They did various actions to deal with dysmenorrhea including drinking herbal medicines $(n=1)$, warm water compresses $(n=3)$, and take a rest $(n=6)$. All of the respondents did not know about guided imagery-relaxation technique. The aim of this study is to assess the effect of guided imagery-relaxation technique on dysmenorrhoea intensity in adolescents.

\section{METHODS}

This study applied the quasi-experiment design with one-group pretest-posttest design without the control group. The effectiveness of the intervention was assessed by comparing the score of post and pre-test (Dharma, 2011). Hypothesis on this researcher was the alternative hypothesis (Ha): There is an influence of imagery relaxation on the 
intensity of dysmenorrhoea in adolescents. While the null hypothesis (Ho): There is no effect of imagery relaxation on the intensity of dysmenorrhoea pain in adolescents.

The population in this study were all female students of year $\mathrm{X}$ a public school of the 5th senior high school (SMA) in Cimahi district. The students had experienced primary dysmenorrhea. 182 female students involved in this study. The sampling technique was the purposive sampling technique. The purposive sampling technique is a technique in selecting respondent with some particular criteria that decided by researcher base on their consideration of previous study or characteristic (Notoatmodjo, 2010). The research instrument in this study was the Numeric Rating Scale and SOP of Guided Imagery (Kozier \& Erb, 2009)

The data were analyzed using univariate and bivariate analysis.

a. Univariate analysis

The univariate analysis aimed to describe the characteristics of each research variable (Notoatmodjo, 2010). The form of univariate analysis depends on the type of data. In this study, univariate analysis was used to determine the average pain scale of dysmenorrhoea before and after intervention (Dahlan, 2012). The formula includes Mean (rates) applied because of the data variables were interval and ratio and had a normal distribution (Dahlan, 2012).

$\begin{array}{ll}\mathrm{X} & x=\frac{\text {,àëxi }}{n} \\ \sum_{\mathrm{n}}^{\mathrm{xi}} & \begin{array}{l}: \text { Mean } \\ : \text { the amount of each data } \\ \text { : the amount data }\end{array}\end{array}$


The median divided the data into two parts: $50 \%$ of the data above the median and $50 \%$ of the data below the median. Median was also divided into two types of calculations: the median of single data and the median of group data. The single data were found by sorting the data from the smallest data to the largest or vice versa from the largest data to the smallest data. And then the median position is searched by the formula:

$\operatorname{Me}=1 / 2(n=1)$ where $n=$ the amount of data.

In this study, the univariate analysis used the median, because the normality test data found the data were not normally distributed with the p-value $<0.05$.

\section{b. Bivariate analysis}

The bivariate analysis aimed to test whether guided imagery-relaxation technique had affected to dysmenorrhoea pain in adolescents. The bivariate analysis in this study was conducted to analyze one variable that was measured twice (pretest and posttest) using a nonparametric test: the Wilcoxon test because the normality test data found the data were not normally distributed with $\mathrm{p}$ value $<0.05$.

Bivariate analysis performed when data were not normally distributed (Riyanto, 2013) using a nonparametric test which is the Wilcoxon test formula was:

$$
Z=\frac{T-\neg \mu T}{t T}
$$

$\mathrm{T}=$ Number of levels $/$ the smallest ranking

$$
\mathrm{CE}-\mathrm{T}=\frac{\mathrm{n}(\mathrm{n}+1)}{4}
$$


$\mathrm{tT}=\sqrt{\frac{\mathrm{n}(\mathrm{n}+1)(2 \mathrm{n}+1)}{24}}$

\section{RESULTS}

Table 1 Sclerosis Dysmenorrhea before Guided Imagery- a Relaxation technique

\begin{tabular}{ccccc}
\hline Variable & Median & Minimum & Maximum & N \\
\hline Dysmenorrhoea pain & 5,00 & 2 & 9 & 28
\end{tabular}

Table 1 present that the median was 5.00 (moderate pain) before interventions.

The minimum score was 2 (mild pain), and the maximum 9 (severe pain).

Table 2 Dysmenorrhoea Scale After Guided Imagery-Relaxation technique

\begin{tabular}{lcccc}
\hline Variable & Median & Minimum & Maximum & N \\
\hline Dysmenorrhoea & 2,50 & 0 & 8 & 28 \\
\hline
\end{tabular}

Table 2 reveals that the median was 2.50 (mild pain) with a minimum value 0 (no pain) and maximum 8 (severe pain).

Tabel 3 Effect of Guided Imagery-Relaxation technique to the intensity of dysmenorrhoea

\begin{tabular}{|c|c|c|c|c|c|}
\hline Variable & Median & Min. & Max. & P-Value & $\mathbf{N}$ \\
\hline Dysmenorrhea pain & & & & & \\
\hline $\begin{array}{l}\text { Before performed Guided Imagery - a } \\
\text { Relaxation technique }\end{array}$ & 5,00 & 2 & 9 & 0,000 & 28 \\
\hline $\begin{array}{l}\text { After performed Guided Imagery } \\
\text { Relaxation technique }\end{array}$ & 2,50 & 0 & 8 & & \\
\hline
\end{tabular}


Table 3 shows that dysmenorrhoea scale before the guided imagery-relaxation technique was 5.00 while after the intervention was 2.50 . There was a significant differences before and after interventions with a value of P-value $=0,000<(\alpha=0.05)$. These results indicated that there was an influence of guided imagery-relaxation technique to the scale of dysmenorrhoea before and after interventions in year X student of SMA 5 Cimahi district.

\section{DISCUSSION}

\section{The Dysmenorrhoea Level Before And After Guided Imagery-Relaxation}

\section{Technique Interventions}

The results of the study showed that the dysmenorrhoea scale before the guided imagery-relaxation technique was 5.00 (moderate pain) with a minimum scale was 2 (mild pain) and maximum 9 (severe pain). This result in line with a research conducted by Rakhma (2012) who divided the level of dysmenorrhoea into three levels: mild. Moderate, and severe pain. Students experienced mild pain (60 students), moderate dysmenorrhea (44 students) and severe pain (25 students). The majority of students experienced mild pain.

This study finding is in agreement with Proverawati and Misaroh (2009) which stated that the dysmenorrhoea experience was caused by the contraction of the uterus (the uterus) that stimulated by prostaglandin production excessively. The pain was getting severe when the clotted blood from the uterus passed through the cervix (cervix), especially if the cervical canal is narrow.

This study revealed that students with mild dysmenorrhea said that pain was in the lower abdomen, and did not interfere in their activities. They already adapted to 
mild pain and they responded calmly. This finding is in relation to Solehati and Kosasih (2015) the theory of effect said that pain is an emotional situation. The intensity is depending on clients' interpretation. Students who suffered moderate dysmenorrhea had problems with their activities and affected the learning process. Meanwhile, students who experience severe pain in the lower abdomen, the pain spreads to the waist, thighs, and body weakness caused disruption of their school activities. This may due to the excessive prostaglandins from uterine endometrial cells, prostaglandin-F2 $\alpha$ was a strong stimulant of myometrium muscle and uterine venous contraction resulting in severe pain during menstruation (Elizabeth \& Corwin, 2009). The interviews results found other factors influence severe pain including fatigue and lack of exercise.

\section{The Dysmenorrhoea Scale After Guided Imagery-A Relaxation Technique}

The scale of dysmenorrhoea after the intervention was 2.50 (mild pain) with standard deviation 2,342. The minimum value was 0 (no pain) and a maximum was 8 (severe pain). The results showed that there were 2 respondents who did not experience pain, 14 respondents with mild pain, 8 respondents with moderate pain, and 4 respondents with severe pain. In this study, the intervention was changed on the pain scale of 25 respondents. However, 3 respondents did not experience any changes in pain scale. The results of this study are in line with the research conducted by Suciana (2016) that there was a significant decrease on menstrual pain before and after the guided image-relaxation technique the score of pain before was 2.50 and after was 2.00 with pvalue 0.000 smaller than 0,05 . It can be concluded that relaxation imagery techniques influence in reducing menstrual pain. 
The decrease of dysmenorrhoea pain intensity during therapy would occur due to the increase of enkephalin production by the adrenal medulla which also produces endorphin neurotransmitters. The endorphin would affect the mood to relax and relieve pain. Guided Imagery-Relaxation technique used an imagination to achieve positive and if it applied properly, it would give a relax and comfortable effects. When respondents take a breath deeply, the body will feel relaxed. This technique can be used as an endorphin release effort. Endorphins and enfekalin are other substances or more substances such as morphine produced in the body that acts as an inhibitor of pain transmission, so when the body releases these substances, one effect is pain relief (Smeltzer \& Bare, 2013).

The results showed after intervention found that the guided imagery- relaxation therapy showed significant results with p-value $0,000<\alpha=0,05$. It can be concluded, guide imagery-relaxation therapy can reduce the intensity of pain in dysmenorrhoea. If it applied regularly, female students who experience dysmenorrhoea would drop significantly.

This is in line with the statement expressed by Fountaine (2005) in Solehati and Kosasih (2015) that the relaxation of guide imagery can create mental images to stimulate physical changes in the body and generate a strong psychological response such as a change in immune function. For 3 students who did not experience a change in pain scale, other factors may influence this situation such as the decreased of physical conditions such as fatigue and lack of nutritional intake, it could increase pain intensity and endorphins because endorphin levels differed. 


\section{Effect of Guide Imagery-Relaxation Therapy on Dysmenorrhea Relief}

The statistical test results obtained $\mathrm{p}$-value $=0,000<\alpha 0.05$. This indicated that there was a significant effect of guided imagery relaxation on the intensity of dysmenorrhea. The results of this study were also supported Santoso, et al (2016) found that after guided imagery- relaxation $\mathrm{p}<0.001$ ( $\mathrm{p}$-value $<\alpha$ 0.05), There was an influence before and after the intervention of guided imagery to painful menstruation. The results of this study were also strengthened by Suciana's (2016) research in Pedan State Vocational School that the results found the decrease in dysmenorrhoea level after guided imagery-relaxation intervention with p-value $0,000<\alpha=0,05$, which means there was a significant influence this intervention to reduce painful menstruation.

The median of the dysmenorrhea scale after the intervention was lower than the median before the intervention. The guided imagery-relaxation technique is one of the nonpharmacological interventions that is effective to reduce dysmenorrhoea (Solehati and Kosasih, 2015). The relaxation intervention of the guided imagery consists of slow rhythmic breathing and a mental image of relaxation with comfort and relaxation. The feeling of relaxed will be forwarded to the hypothalamus to produce Corticotropin Releasing Factor (CRF). Furthermore, CRF stimulates the anterior pituitary gland to increase the production of pro-opiomelanocortin (POMC) which causes increased production of enkephalin by the adrenal medulla, then produces endorphin neurotransmitters which are believed influence mood relaxes (Guyton \& Hall, 2006).

This finding is in agreement with Ariyani's (2007) study stated that guided imagery relaxation aimed to change the perception of pain, calm the mind, avoid the effects of stress and reduce tension, lower blood pressure, increase body relaxation, change pain perception and decrease pain. This also supported by the gate control 
theory that imagery relaxation would inhibit or regulate the impulse defense mechanisms along the central nervous system. This theory said that a pain impulse delivered when a defense gate opened, and an impulse inhibited when a defense gate closed. A positive image of the sensory neurons and the descendent controls of the brain governing the defense process. Delta neurons $\mathrm{A}$ and $\mathrm{C}$ released substance $\mathrm{C}$ and $\mathrm{P}$ to transmit pain impulses through defense mechanisms. In addition, the thicker mechanoreceptor of beta-neuronal A which release the neurotransmitter inhibitory. If the dominant input comes from beta $\mathrm{A}$ it would close the defense mechanism (Potter and Perry, 2006).

The message would stimulate the mechanoreceptor, if the dominant input was from the fiber of delta $\mathrm{A}$ and fiber $\mathrm{C}$, it would open the defenses and the client would perceive the sensation of pain. If the impulse delivered to the brain, there was a higher cortical center in the brain that modifies pain. The descending nerve pathways release endogenous opiates, such as endorphins, as a painkiller naturally derived from the body by inhibiting the release of substance P (Potter and Perry, 2006 and Proverawati \& Misaroh, 2009). This inline Potter \& Perry, (2006)' stated that increasing the production of endorphin hormones, relaxation guide imagery was also useful for lowering blood pressure, breathing, oxygen consumption, muscle tension, and metabolism. Increasing attention to environmental stimuli, feelings of peace and prosperity. Providing individual control when there is discomfort or pain, physical and emotional stress because of pain. Preventative actions to refresh.the body 


\section{CONCLUSION}

The scale of dysmenorrhea before guide imagery relaxation therapy was 5.00 (medium) with the lowest scale 2 and the highest scale was 9. The scale of dysmenorrhea after the intervention was 2.50 (light dysmenorrhea scale) with the lowest score was 0 and the highest score was 8. There was a significant influence of guide imagery-relaxation technique on pain intensity of dysmenorrhoea with $\mathrm{p}$-value $=0,000<\alpha(0,05)$. It means Ha rejected. 25 out 28 respondents experienced a decrease of pain, and another 3 had no changes on the pain scale.

The results of this study is a potential source for teaching material in nursing education, especially how to deal with dysmenorrhea. This method is expected as science reference related to relaxation therapy for guide imagery especially for female students who experience dysmenorrhoea. The future would assess the effectiveness of different methods such as by adding a control group with different variables, as well as the time to give guided imagery relaxation for 1 day 2 times in more than 2 weeks and do a comparison of other non-pharmacological methods in addition to relaxation guide imagery to prevent and overcome dysmenorrhoea.

\section{REFERENCES}

Aziz, A. (2009). Kebutuhan Dasar Manusia. Jakarta: Salemba Medika.

Ariyani. (2007). Terapi Modalitas Keperawatan. Jakarta: Universitas Indonesia.

Dahlan, M. S. (2013). Besar Sampel dan Cara Pengambilan Sampel dalam Penelitian Kedokteran dan Kesehatan (3 ed.). Jakarta: Salemba Medika.

(2012). Statistik untuk Kedokteran dan Kesehatan. Jakarta: Salemba Medika.

Darma, K. K. (2011). Metedologi Penelitian Keperawatan. Jakarta: Trans Info Media. 
Elizabeth, J., \& Corwin. (2009). Buku Saku Patofisiologi. Jakarta: EGC.

Format referensi elektronik direkomendasikan oleh Santoso, 2016, tersedia http://digilib.stikeskusumahusada.ac.id, 20 Febuari 2017.

Hidayat, A. A. (2013). Metode Penelitian Keperawatan dan Teknik Analisis Data. Jakarta: Salemba Medika.

Janiwarti, B., \& Pieter, H. Z. (2013). Pendidikan Psikologi Untuk Bidan-Suatu Teori dan Terapannya. Yogyakarta: Rapha Publishing.

Kozier, \& Erb. (2009). Buku Ajar Praktik Keperawatan Klinis (5 ed.). Jakarta: EGC.

Kumalasari, I., \& Andhyantoro, I. (2012). Kesehatan Reproduksi Untuk Mahasiswa Kebidanan Dan Keperawatan. Jakarta: Salemba Medika.

Kusmiran, E. (2011). Kesehatan Reproduksi Remaja Dan Wanita. Jakarta: Salemba Medika.

Laila, N. N. (2011). Buku Pintar Menstruasi. Yogyakarta: Buku Biru.

Lestari, T. W., Ulfania, E., \& Suparmi. (2011). Buku Ajar Kesehatan Reproduksi Berbasis Kompetensi. Jakarta: EGC.

Mubarak, W. I. (2007). Kebutuhan Dasar 'usia. Jakarta: EGC.

Notoatmodjo, S. (2010). Metedologi Penelitian Kesehatan. Jakarta: Rineka Cipta.

Puji. (2011). Efektivitas Senam Dismenore Dalam Mengurangi Dismenore Pada Remaja Putri Di SMUN Semarang. Pengaruh Dismenorea Pada Remaja, 1.

Potter, \& Perry. (2006). Buku Ajar Fundamental Keperawatan (4 ed., Vol. 2). Jakarta: EGC.

Prawirohardjo, S. (2014). Ilmu Kebidanan. Jakarta: Yayasan Bina Sarwono Prawirohardjo. . (2014). Ilmu Kandungan. Jakarta: PT Bina Pustaka Sarwono Prawirohardjo.

Proverawati, A., \& Misaroh, S. (2009). Menarche Menstruasi Penuh Makna. Yogyakarta: Nuha Medika.

Puji. (2011). Efeketivitas Senam Disminore Dalam Mengurangi Disminore pada Remaja Putridi SMUN 5 Semarang. 
Riyanto, A. (2011). Aplikasi Metedologi Penelitian Kesehatan. Yogyakarta: Nuha Medika.

\section{Medika.}

(2011). Pengolahan dan Analisis Data Kesehatan. Yogyakarta: Nuha

Simanjuntak, P. (2008). Gangguan Haid dan Siklusnya. Jakarta: Bina Pustaka Sarwono Prawirohardjo.

Sadock, \& Kaplan. (2013). Buku Ajar Psikiatri Klinis (2 ed.). Jakarta: EGC.

Sugiyono. (2016). Statistika untuk Penelitian. Bandung: Alfabeta.

Susana, S. A., \& Hendarsih, S. (2012). Terapi Modalitas Keperawatan Kesehatan Jiwa. Jakarta: Buku Kedoketran EGC.

Smeltzer, \& Bare. (2013). Buku Ajar Medikal Bedah (8 ed., Vol. 1). Jakarta: EGC.

Soetjoningsih. (2010). Bahan Ajar: Tumbuh Kembang Remaja dan Permasalahannya. Jakarta: Sagung Seto.

Solehati, T., \& Kosasih, C. E. (2015). Konsep \& Aplikasi Relaksasi dalam Keperawatan Maternitas. Bandung.

Widyastuti, Y., Rahmawati, A., \& Purnamaningrum, Y. E. (2009). Kesehatan Reproduksi. Yogyakarta: Fitrimaya.

Wiknjosastro, H. (2007). Ilmu Bedah Kebidanan. Jakarta: Yayayasan Bina Pustaka.

Yudianta, \& dkk. (2015). Assesment Nyeri. Teknik , 2. 